Original Research Paper

\title{
Specialty Dihydrobenzoxanthone's Artocarpus Purified By Vacuum Liquid Chromatography (VLC)
}

\author{
Aliefman Hakim* \\ Study Program of Chemistry Education, Faculty of Teacher Training and Education, University of \\ Mataram, J1 Majapahit No.62, Mataram, 83125, Indonesia.
}

\author{
Article History \\ Received : May $04^{\text {th }}, 2021$ \\ Reviced : May $12^{\text {th }}, 2021$ \\ Accepted : May $27^{\text {th }}, 2021$ \\ Published : June $02^{\text {th }}, 2021$ \\ *Corresponding Author: \\ Aliefman Hakim, \\ Study Program of Chemistry \\ Education, Faculty of Teacher \\ Training and Education, \\ University of Mataram, \\ Indonesia. \\ Email: \\ aliefmanhakim27@gmail.com
}

\begin{abstract}
One family of plants that are source of bioactive chemicals is the Moraceae. Artocarpus is the main genus of the Moraceae. Several species of the genus Artocarpus have been isolated their secondary metabolites. The main fractions obtained from the VLC are analyzed again by TLC. Fractions that have same spots (Rf) pooled. Purification process on main factions are done repeatedly by radial chromatography. Flavonoid is the most found from Artocarpus plant. Dihydrobenzoxanthone is one of flavonoid derivatives which is successfully isolated from Artocarpus. Dihydrobenzoxanthone is only formed from the flavone with ring B which is oxygenated with pattern of 2', 4' and 5'. Students can be learned dihydrobenzoxanthone's Artocarpus by laboratory activities.
\end{abstract}

Keywords: Artocarpus, dihydrobenzoxanthone, students.

\section{Introduction}

Plants contain secondary metabolites that can be extracted for scientific, technological and commercial purposes. Most plant species grow in tropical climates. Indonesia as a tropical country has a very high diversity of plants. Indonesia has 25,000 high-level plant species and $40 \%$ are Indonesian endemic plants (Achmad, 1995). However, the abundant natural wealth has not been studied, recorded and reviewed, so that it cannot be utilized optimally.

In the field of traditional medicine there are many species that have reported, but research on the useful of chemicals content in plant has not much in Indonesia. One group of plants that has benefits in the field of medicine is the family of Moraceae, specifically the genus Artocarpus (Heyne, 1987).

Artocarpus belongs to the clan of jackfruit plants. Plant species included in this genus such as jackfruit or breadfruit which are widely used for fruit, wood, skin, and sap. Research on the chemical content of the genus Artocarpus has been carried out. The chemical compounds reported in the Artocarpus include triterpenes, steroids, flavonoids, stylbenoids, and lignans (Ahmad, 1996) (Nomura, 1998). The phenolic compound which is the most abundant compound found in the genus Artocarpus is a class of flavonoids. These phenolic compounds are reported to have anti-bacterial activity (Khan, 2003), anti-fungal (Jayasinghe, et. al, 2004), anti-malaria (Widyawaruyanti, et. al, 2007) and cytotoxic (Syah, et. al, 2006).

Antimalarial activity-guided study of the aerial parts of Artocarpus integer led to the isolation of the prenylated stilbene, trans-4-(3methyl-E-but-1-enyl)-3,5,2',4'-

tetrahydroxystilbene (Boonlaksiri, 2000). Phytochemical testing of jackfruit leaf (Artocarpus heterophyllus Lmk) showed that belong to flavonoide compounds and antibacterial testing of flavonoid compounds Staphylococcus aureus with a concentration of 10.000 ppm inhibited 10.50 (Darmawati, 2015). Other reaserch showed Artocarpus altilis (Parkinson) ethyl acetate extract showed cytoprotective activities (Wang, 2006).

The benefits and uses of Artocarpus in the health sector and easily found everywhere are an interesting aspect. This study aims to facilitate the isolation of active compounds from Artocarpus as basic ingredients and standards in various scientific studies such as microbiology and pharmacy. Isolated compounds can be further tested as active natural substances against various types of diseases. 


\section{Materials and Method}

\section{Extraction, Isolation, and Purification}

The method for making extracts consists of powder, extraction, solvent separation, and extract concentration. The extraction process is repeated until the less colorful supernatant. Solvent separation used a rotary evaporator and concentrated in a water bath, so a crude extract produced.

Futhermore, the obtained extraction is underwent TLC (Thin Layer Chromatography) treatment using various eluents. TLC chromatogram is used as a basis for conducting fractionation by vacuum liquid chromatography (VLC). The main fractions obtained from the VLC are analyzed again by TLC. Fractions that have same spots (Rf) pooled. Purification process on main factions are done repeatedly by radial chromatography. TLC chromatogram is used to test the purity of an isolate, the pure compound must show a single spot on three different eluent systems. The purity test can also be done by measuring its melting point.

\section{Result and Discussion}

\section{Structural Determination}

The structures of pure compound are determined by spectroscopic methods: (i) UVVis spectrum to determine the presence of double bond conjugation in the structure of pure compound. (ii) Infrared spectrum to know the functional groups. (iii) NMR (Nuclear Magnetic Resonances) is a great tools for determinining of pure compound (Okunlola, 2019).

\section{Flavonoids}

The flavonoid pigments, one of the most numerous and widespread groups of natural constituents, are of importance and interest not only because of their significant natural functions in the economy of the plant, but also because certain members of the group are physiologically active in humans (Harborne et al. 1991). The flavonoids are derived from the flavan or isoflavan skeleton and comprise a large group of secondary metabolites from higher plants. The sites of plant flavonoid biosynthesis, storage and final function often differ at the subcellular, cell, and even tissue and organ levels. Efficient transport systems for flavonoids across endomembranes and the plasma membrane are therefore required (Zhao, et al., 2010).

The flavonoid compounds of Artocapus have variety of frameworks such as chalkon derivatives, flavanones, flavan-3ol, simple flavone, prenylflavone, oxepinoflavone, pyranoflavone, dihydrobenzoxanthone, furanodihydrobenzoxanthone, pyranodihydrobenzoxanthone,

quinonoxanthone, cyclopentenoxanthone, xanthonolide, dihydroxanthone, and cyclopentenoxanthone. This article will be described dihydrobenzoxanthone that have been isolated from Artocapus.

\section{Dihydrobenzoxanthone}

Dihydrobenzoxanthone is formed from C6' in ring B bound directly to the carbon from the group of prenyl hexagon forms a ring. Dihydrobenzoxanthone formed from the flavone with B ring which was oxygenated with pattern of 2', 4' and 5'. The two hydroxy groups at $\mathrm{C} 2$ ' and $\mathrm{C}^{\prime}$ ' activated $\mathrm{C} 6$ ' which was located at the ortho position of hydroxy group (Hakim, 2010).

Class of dihydroxanthone compounds which have been isolated are artobiloxanthone (1) which are isolated from the stem bark of $A$. scortechinii by Ferlinahayati (Ferlinahayati, 1999) (Pratap,2014). Compound (1) is also isolated from A. nobilis (Sultanbawa, et. al, 1989) (Jayasinghe ULB, et. al, 2008)). Syah et al. (2002) is succeeded in isolating artoindonesianin $\mathrm{S}(\mathbf{2})$ and artoindonesianin T ( $\mathbf{3})$ of stem wood of A. champeden (Syah, et. al, 2002). A full set of kinetic study has been completed for dihydrobenzoxanthones (1-4) to be competitive and reversible simple slow-binding inhibitors in $\alpha$-glucosidase and has rarely been reported from natural phenolic compounds ((Jenis, et. al, 2019).<smiles>C=C(C)C1Cc2c(oc3c4c(cc(O)c3c2=O)OC(C)(C)C=C4)-c2c(O)cc(O)c(O)c21</smiles>

(1)<smiles>C=C(C)C1Cc2c(oc3cc([OH2+])cc(O)c3c2=O)-c2c(O)cc(OCC)c(O)c21</smiles>

(2) $\mathrm{R}_{1}=\mathrm{R}_{2}=\mathrm{CH}_{3}$ (3) $\mathrm{R}_{1}=\mathrm{H}, \mathrm{R}_{2}=\mathrm{CH}_{3}$

Figure 1. Dihydrobenzoxanthones 
If we look carefully, it can be seen that the ring $\mathrm{B}$ oxidation pattern of dihydroxanthone compounds is not in accordance with the pattern of the acetate malonate pathway and the shikimat pathway which is the biogenesis pathway of the flavonoid group.

\section{Conclusion}

Dihydrobenzoxanthone is one of flavonoid derivatives which is successfully isolated from Artocarpus. Dihydrobenzoxanthone is only formed from the flavone with ring $\mathrm{B}$ which is oxygenated with pattern of 2', 4' and $5^{\prime}$. the ring $\mathrm{B}$ oxidation pattern of dihydroxanthone compounds is not in accordance with the pattern of the acetate malonate pathway and the shikimat pathway which is the biogenesis pathway of the flavonoid group.

\section{Acknowledgments}

We wish to thank the Ministry of Research, Technology and Higher Education, Indonesia for funding the research.

\section{References}

Achmad, S.A., Hakim, E. H.,. Juliawaty, L. D., Makmur., L., \& Suyatno (1996), New Prenylated Flavone from Artocarpus champeden, J. Nat Prod, 59, 878-879. https://doi.org/10.1021/np960330q

Achmad, S.A., Hakim, E. H.,. Juliawaty, L. D., Makmur., L., Kusuma, S. \& Syah, Y. M. (1995), Eksplorasi Kimia Tumbuhan Tropis Indonesia, Seminar Nasional Etnobotani II, Yogyakarta, 112-113.

Boonlaksiri, C., Oonanant, W., Kongsaeree, P., Kittakoop, P., Tanticharoen, M., \& Thebtaranonth, Y. (2000). An antimalarial stilbene from Artocarpus integer. Phytochemistry, 54(4), 415-417. https://doi.org/10.1016/S00319422(00)00074-1

Darmawati, A. A. S. K., Bawa, I. G. A. G., \& Suirta, I. W. (2015). Isolasi dan Identifikasi Senyawa Golongan Flavonoid pada Daun Nangka (Artocarpus heterophyllus Lmk) dan Aktivitas

\section{Antibakteri terhadap Bakteri Staphylococcus aureus. Jurnal Kimia (Journal of Chemistry).}

Ferlinahayati (1999). Norartokarpetin dan flavonoid terisoprenilasi dari kulit batang Artocarpus scortechinii King [Tesis]. Institut Teknologi Bandung. Bandung

Hakim, A. (2010). Diversity of secondary metabolites from Genus Artocarpus (Moraceae). Nusantara Bioscience, 2(3). https://doi.org/10.13057/nusbiosci/n0203 $\underline{07}$

Heyne, K., (1987), Tumbuhan Berguna Indonesia II, Terjemahan, Penerbit Badan Litbang Kehutanan, Jakarta, 645-646.

Jayasinghe ULB, Samarakoon TB, Kumarihamy BMM, Hara N, \& Fujimoto Y. (2008). Four new prenylated flavonoids and xanthones from the root bark of Artocarpus nobilis. Fitoterapia 79: 37-41. https://doi.org/10.1016/j.fitote.2007.07.01 $\underline{4}$

Jayasinghe, L., Balasooriya, B.A.I.S., Padmini,W.C., Hara, N., \& FujimotoY. (2004). Geranyl chalcone derivatives with antifungal and radical scavenging properties from the leaves of Artocarpus nobilis, Phytochemistry, 65, 1287-1290. https://doi.org/10.1016/j.phytochem.2004 .03 .033

Jenis, J., Baiseitova, A., Yoon, S. H., Park, C., Kim, J. Y., Li, Z. P., ... \& Park, K. H. (2019). Competitive $\alpha$-glucosidase inhibitors, dihydrobenzoxanthones, from the barks of Artocarpus elasticus. Journal of enzyme inhibition and medicinal chemistry, 34(1), 1623-1632. https://doi.org/10.1080/14756366.2019.1 660653

Khan, M.R., Omoloso, A.D., \& Kihara, M., (2003) Antibacterial activity of Artocarpus heterophyllus, Fitoterapia, 74, 501-505. https://doi.org/10.1016/S0367$\underline{326 \times(03) 00120-5}$

Nomura, T., Hano, S., \& Aida M. (1998), Heterocycles, 47(2), 1179-1205. 
https://www.infona.pl/resource/bwmeta1. element.elsevier-6717c273-ac61-3f948497-dc82cb7add9b

Okunlola, A., \& Adewusi, S. A. (2019). Development of theophylline microbeads using pregelatinized breadfruit starch (artocarpus altilis) as a novel co-polymer for controlled release. Advanced pharmaceutical bulletin, 9(1), 93. https://dx.doi.org/10.15171\%2Fapb.2019. $\underline{012}$

Pratap, R., \& Ram, V. J. (2014). Natural and synthetic chromenes, fused chromenes, and versatility of dihydrobenzo [h] chromenes in organic synthesis. Chemical reviews, 114(20), 10476-10526. https://doi.org/10.1021/cr500075s

Sultanbawa, M.U.S., Surendrakumar, \& Sivagnanasundram. (1989). Two pyranodihydrobenzoxanthones from Artocarpus nobilis. Phytochemistry 28(2): 599-605. https://doi.org/10.1016/0031$\underline{9422(89) 80059-7}$

Syah YM, Achmad SA, Ghisalberti EL, Hakim EH, Makmur L, \& Mujahidin D. (2002). Artoindonesianins Q-T, four isoprenylated flavones from Artocarpus champeden Spreng. (Moraceae). Phytochem $61 \quad 949-953$. https://doi.org/10.1016/S00319422(02)00366-7

Syah, Y.M., Juliawaty, L.D., Achmad, S.A, Hakim, E.H., \& Ghisalberti, E.L, (2006) Cytotoxic prenylated flavones from Artocarpus champeden, Journal Natural Medicine, $\quad 60, \quad 308-312$. https://link.springer.com/article/10.1007/s 11418-006-0012-z

Wang, Y., Deng, T., Lin, L., Pan, Y., \& Zheng, $X$. (2006). Bioassay-guided isolation of antiatherosclerotic phytochemicals from Artocarpus altilis. Phytotherapy Research: An International Journal Devoted to Pharmacological and Toxicological Evaluation of Natural Product Derivatives, 20(12), 1052-1055. https://doi.org/10.1002/ptr.1990
Widyawaruyanti, A., Subehan, Kalauni, S.K., Awale, S., Nindatu, M., Zaini, N.C., Syafruddin, D., Asih, P.B.S.,Tezuka, Y., ... Kadota, S. (2007), New prenylated flavones from Artocarpus champeden, and their antimalarial activity in vitro, Journal Natural Medicine, 61, 410-413.

Zhao, J., \& Dixon, R. A. (2010). The 'ins' and 'outs' of flavonoid transport. Trends in plant science, 15(2), 72-80. https://doi.org/10.1016/j.tplants.2009.11. $\underline{006}$

Harborne, J. B. (1989). Flavonoids. In Natural products of woody plants (pp. 533-570). Springer, Berlin, Heidelberg. https://link.springer.com/chapter/10.1007 1978-3-642-74075-6 16 